\title{
Role of Hepatitis C Virus Genotype 3 in Liver Fibrosis Progression - A Systematic Review and Meta-Analysis
}

${ }^{1}$ Probst A., ${ }^{2}$ Dang T., ${ }^{3}$ Bochud M., ${ }^{4}$ Egger M., ${ }^{5}$ Negro F., ${ }^{1}$ Pierre-Yves B.

Infectious Disease Service - CHUV', Internal Medicine Service - CHUV', Institute for Social and Preventive Medicine $\mathrm{CHUV}^{3}$, Institute for Social and Preventive Medicine - Bern ${ }^{4}$, Division of Gastroenterology and Hepatology - HUG

Background: It has long been considered that the progression rate of liver fibrosis among chronic $\mathrm{HCV}$ patients is not influenced by the viral genotype. However, recent studies suggested an association between viral genotypes 3 and rapid progression. We performed a systematic review and meta-analysis of published studies evaluating the association between HCV genotypes and fibrosis progression.

Methods: We searched PubMed, Embase and ISI Web of Knowledge databases for studies on treatment naïve $\mathrm{HCV}$ infected-adults with an estimated date of $\mathrm{HCV}$ infection, at least one liver biopsy, and an estimated fibrosis progression rate (FPR). A random-effect model was used to derive FPR among the different HCV genotypes.

Results: Eight single biopsy studies (3182 patients, mean/median duration of infection ranging from 9-21 years) and 8 paired biopsies studies (678 patients, mean interval between biopsies 2-12 years) met the selection criteria. Most patients included in the studies were males (62\%), the most frequent ethnicity was Caucasian (95\%, data available in 5 studies) and the mean age was 42 years. The most frequent routes of infection were intravenous drug use $(41 \%)$ and blood transfusion (31\%). The odds ratio for the association of genotype 3 with accelerated fibrosis progression was $1.52(95 \% \mathrm{Cl} 1.12-2.07, \mathrm{P}=0.007)$ in single biopsy studies. The odds ratio for the association of genotype 3 with fibrosis progression was $1.37(95 \% \mathrm{Cl} 0.87-2.17, \mathrm{P}=0.17)$ in paired biopsy studies.

Conclusion: Viral genotype 3 was significantly associated with faster fibrosis progression when analyzing single biopsy studies. There was a trend toward the same direction when analyzing paired biopsy studies. Paired biopsies studies may have reduced power to detect such associations, due to an important indication bias, small sample size and use of arbitrary dichotomization criteria to assess progression. This observation may have important consequences for the decision to start therapy among genotype 3-infected patients.

Contact Information:

Pierre-Yves Bochud, Infectious Disease Service, Department of Medicine, Rue du Bugnon 46, 1011 Lausanne, Switzerland, mail: pierre-yves.bochud@chuv.ch, Phone: +41213144379 
Faculty of Biology and Medicine

\section{FBM Research Day}

January 27, 2011

César Roux Auditorium

\section{Cardiovascular and \\ Metabolic Disorders

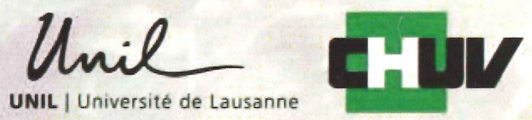

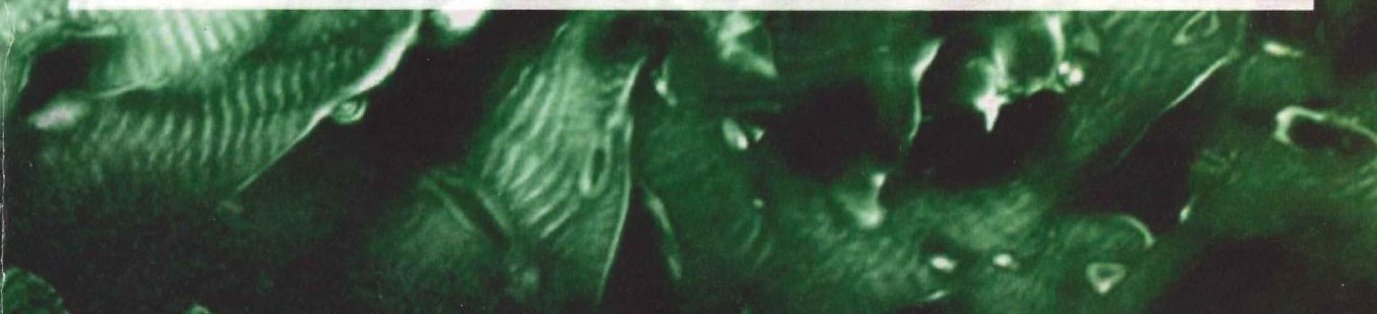




\section{Contents}

Message of the Vice-Dean for Research of the Faculty of Biology and Medicine

Programme

\section{Abstracts}

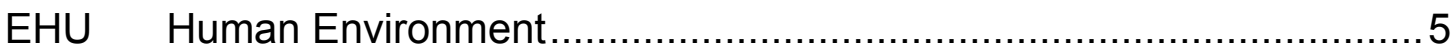

ENA Natural Environment .......................................................... 14

GEN Genes and Environment.................................................... 18

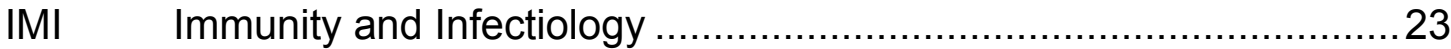

MCV Metabolism and Cardiovascular ............................................. 56

NEU Neurosciences................................................................. 139

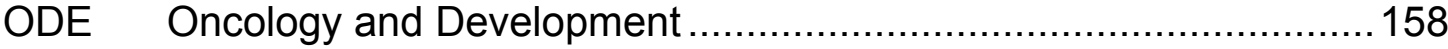

THE Therapeutic Procedures......................................................... 174

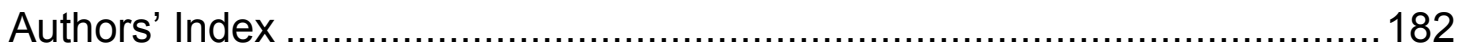

Cover: Yannick Krempp, Department of Cell Biology and Morphology - UNIL

Photos: Epifluorescence microscopy of a mouse heart section showing a-actinin stained cardiomyocytes provided by Philippe Kiehl and Thierry Pedrazini, Experimental Cardiology Unit, CHUV (top) and echocardiographic M-mode image and ECG monitoring of a beating mouse heart provided by Corinne Berthonneche et al., Cardiovascular Assessment Facility \& Experimental Mlcrosurgery Facility (CAF/EMIF), Cardiomet, CHUV (bottom) 

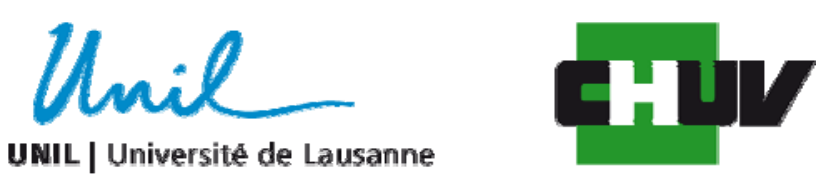

Faculté de biologie et de médecine

\title{
Organisation 2011
}

\section{Scientific Committee}

\author{
Ivan Stamenkovic \\ Institute of Pathology - CHUV \\ Liliane Michalik \\ Center for Integrative Genomics - UNIL \\ Lucia Mazzolai \\ Angiology - CHUV \\ François Pralong \\ Endocrinology, Diabetology and Metabolism - CHUV \\ Gérard Waeber \\ Internal Medicine - CHUV \\ Eric Eeckhout \\ Cardiology - CHUV
}

\section{FBM Organisation Committee}

\author{
Jovan Mirkovitch \\ Zadria Berzin \\ Nathalie Magnenat \\ Anne Tricot
}




\section{Message of the Vice-Dean for Research}

Dear Friends and Colleagues,

On behalf of the Organizing Committee I would like to welcome you to the ninth edition of the CHUV Research Day, which will be dedicated to cardiology and metabolism. Clinical and research development in both fields has been given high priority at the CHUV and UNIL, and the coming years should see significant progress toward the establishment of corresponding clinical and research centres.

Growing evidence indicates that inflammation is causally related to obesity and diabetes. Thus, obesity is associated with low grade systemic inflammation that constitutes one of the mechanisms underlying obesity-associated morbidity. Moreover, chronic inflammation is a significant risk factor for the development of cardiovascular and metabolic disease and continuous secretion of factors such as TNF $\alpha$ and IL-6 is associated with increased risk for numerous chronic diseases including insulin resistance, atherosclerosis and type 2 diabetes.

Given that obesity is a complex disorder, a mutidisciplinary approach is necessary to unravel its pathogenesis and underlying mechanisms. The use of numerous «omic » technologies including genomics, proteomics and metabolomics is becoming essential in order to identify inflammatory biomarkers that may be implicated in the pathogenesis of obesity and the mechanisms that link the increase in adipose mass to morbidity. Once identified, elucidation of the role of the relevant inflammatory factors in the various disorders related to obesity will be essential.

Among cardiovascular diseases, atherosclerosis is linked not only to inflammation but to an adaptive immune response as well. However, whereas the role of Th1 lymphocytes in atherogenesis is well established, less is known about the role of othee T cell subsets, including Th2 and Th17. Elucidation of the full repretoire of mechanisms whereby adaptive immunity enhances atherogenesis will no doubt be important.

The program to which you have been invited will cover a variety of aspects of the implication of inflammation and immunity in obesity and atherogenesis with a view as to possible novel therapeutic approaches down the line.

I would like to thank the Scientific Committee for putting together a high quality program with a superb panel of guest speakers and hope that you will find the event to be both stimulating and enjoyable.

I van Stamenkovic

Vice-Doyen for Research 


\section{Message du Vice-Doyen de la Recherche}

Cher(e)s Collègues, Cher(e)s Ami(e)s,

Je vous souhaite la bienvenue à la neuvième édition de la Journée de Recherche CHUV dont les thématiques sont la cardiologie et le métabolisme. Ces thématiques représentent des domaines de développement prioritaires du CHUV et de I'UNIL et prennent une importance croissante dans notre Faculté.

Les développements récents dans le domaine du métabolisme indiquent que l'inflammation joue un rôle important dans l'obésité et dans le diabète. Ainsi, l'obésité est associée à un état inflammatoire systémique chronique de bas grade qui constitue l'un des mécanismes potentiels impliqué dans les complications de l'obésité. L'inflammation chronique de bas grade est un facteur de risque significatif pour les maladies cardiovasculaires et métaboliques, et la sécrétion continue des médiateurs tels que le TNF $\alpha$ et I'IL- 6 est associée à un risque augmenté pour de nombreuses maladies chroniques y compris la résistance à l'insuline, l'artériosclérose et le diabète de type II.

La physiologie de l'obésité étant complexe, il est évident qu'une approche multidisciplinaire est nécessaire pour comprendre son processus et les mécanismes qui y conduisent. L'utilisation de nouvelles technologies, y compris la génomique, la protéomique et la métabolomique devient indispensable afin d'identifier les biomarqueurs inflammatoires qui pourraient être impliqués dans la pathogénèse de l'obésité ainsi que dans les mécanismes moléculaires qui lient l'augmentation la masse du tissu adipeux aux dysfonctions de l'organisme. II est de ce fait essentiel de comprendre le rôle des différents facteurs inflammatoires dans les affections liées à l'obésité.

Parmi les maladies cardiovasculaires, la pathogénèse de 'artériosclérose est intimement liée à la réponse immune adaptative. Toutefois, alors que le rôle athérogène des lymphocytes Th1 est bien établi, celui des autres sous groupes lymphocytaires T, y compris Th2 et Th 17 l'est moins mais de plus en plus de données suggèrent que ces lymphocytes participent à la régulation de l'artériosclérose et l'élucidation de leur mécanisme d'action sera d'importance.

Le programme auquel vous êtes conviés fait le point sur les approches actuelles de l'analyse de la réponse inflammatoire et immune dans l'obésité et dans l'artériosclérose et examine les voies thérapeutiques possibles.

Je tiens à remercier les membres du comité scientifique pour avoir établi un programme stimulant et de très haute qualité et je vous souhaite de passer une journée agréable.

I van Stamenkovic

Vice-Doyen de la Recherche 
Faculty of Biology and Medicine

FBM RESEARCH DAY 2011

Thursday, J anuary $27^{\text {th }}, 2011$

César-Roux Auditorium, CHUV, Lausanne

Attendance is free - No registration is necessary

\section{“Cardiovascular \& Metabolic Disorders"}

\section{8:45 I van STAMENKOVI C}

Vice Dean for Research

\section{NUTRITION AND METABOLISM}

09:00 Karine CLEMENT

Pierre \& Marie Curie University, Paris, France Human adipose tissue; pathological alteration in obesity and diabetes

09:45 Coffee \& Poster presentations

\section{0:15 PACTT and morning short talks}

11:45 Johan AUWERX

EPFL, Lausanne, Switzerland

Integrating metabolic control by NAD+ sensors

12:30 Lunch, Coffee \& Poster presentations

\section{ATHEROSCLEROSIS \& I NFLAMMATI ON}

$13: 30$

\section{Ziad MALLAT}

Inserm U970, Paris, France

University of Cambridge, Cambridge, UK Adaptive Immunity in Atherosclerosis

14:15 Euresearch and afternoon short talks

$15: 45$

Coffee \& Poster presentations

\section{VASCULAR AGEI NG VASCULAR AGEI NG}

\section{6:15 Pierre BOUTOUYRIE}

G. Pompidou European Hospital, Paris, France Vascular ageing: patholophysiology and basis for therapeutics

17:00

Poster Prize Ceremony

17:30 Apéritif 


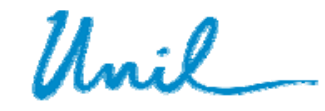

UNIL | Universitê de Lausanne

Faculté de biologie et de médecine

\begin{tabular}{|c|c|c|}
\hline Schedule & Names \& Departments & Titles \\
\hline \multicolumn{3}{|l|}{ Morning } \\
\hline $10 h 15-10 h 30$ & $\begin{array}{l}\text { Stefan KOHLER } \\
\text { PACTT - UNIL/CHUV }\end{array}$ & $\begin{array}{l}\text { From the lab to the market: } \\
\text { Commercialisation of research results }\end{array}$ \\
\hline $10 h 30-10 h 45$ & $\begin{array}{l}\text { Cécile J ACOVETTI } \\
\text { Department of Cellular Biology } \\
\text { and Morphology - UNIL }\end{array}$ & $\begin{array}{l}\text { The role of micro-RNAs in beta-cell mass } \\
\text { expansion during pregnancy }\end{array}$ \\
\hline $10 \mathrm{~h} 45-11 \mathrm{~h} 00$ & $\begin{array}{l}\text { Pedro MARQUES-VI DAL } \\
\text { Social and Preventive Medicine } \\
\text { CHUV }\end{array}$ & $\begin{array}{l}\text { Prevalence and management of } \\
\text { cardiovascular risk factors among } \\
\text { migrants in Switzerland }\end{array}$ \\
\hline $11 \mathrm{~h} 00-11 \mathrm{~h} 15$ & $\begin{array}{l}\text { Francesca AMATI } \\
\text { Department of Physiology - UNIL and } \\
\text { Service of Endocrinology, Diabetology } \\
\text { and Metabolism - CHUV }\end{array}$ & $\begin{array}{l}\text { Skeletal muscle mitochondrial content } \\
\text { and electron transport chain activity in } \\
\text { older adults at risk for type } 2 \text { diabetes: } \\
\text { relationship to insulin sensitivity, } \\
\text { metabolic flexibility and fatty acid } \\
\text { oxidation }\end{array}$ \\
\hline $11 h 15-11 h 30$ & $\begin{array}{l}\text { Evrim J ACCARD } \\
\text { Departement of Physiology } \\
\text { UNIL }\end{array}$ & $\begin{array}{l}\text { Involvement of the RasGAP-derived } \\
\text { fragment } N \text { in the resistance of } \\
\text { pancreatic beta cells towards apoptosis }\end{array}$ \\
\hline $11 \mathrm{~h} 30-11 \mathrm{~h} 45$ & $\begin{array}{l}\text { Luca CARI OLATO } \\
\text { Institute of Pharmacology and } \\
\text { Toxicology - UNIL }\end{array}$ & $\begin{array}{l}\text { Characterization of novel hypertrophic } \\
\text { pathways activated by the AKAP-Lbc } \\
\text { signalling complex in cardiomyocytes }\end{array}$ \\
\hline \multicolumn{3}{|l|}{ Afternoon } \\
\hline $14 \mathrm{~h} 15-14 \mathrm{~h} 30$ & $\begin{array}{l}\text { Sasha HUGENTHOBLER } \\
\text { Euresearch }\end{array}$ & $\begin{array}{l}\text { European funding opportunities for health } \\
\text { and health related research }\end{array}$ \\
\hline $14 \mathrm{~h} 30-14 \mathrm{~h} 45$ & $\begin{array}{l}\text { Mohammed NEMI R } \\
\text { Experimental Cardiology Unit } \\
\text { CHUV }\end{array}$ & $\begin{array}{l}\text { Cardiac-specific overexpression of the } \\
\text { Notch ligand J agged1 reduces cardiac } \\
\text { hypertrophy and fibrosis in response to } \\
\text { hemodynamic stress }\end{array}$ \\
\hline $14 h 45-15 h 00$ & $\begin{array}{l}\text { Hoshang FARHRAD } \\
\text { Service of Nuclear Medicine } \\
\text { CHUV }\end{array}$ & $\begin{array}{l}\text { Myocardial Blood Flow Quantification with } \\
\text { Rubidium-82 Cardiac PET has } \\
\text { Incremental Prognostic Value in Patients } \\
\text { with Known or Suspected Coronary } \\
\text { Artery Disease }\end{array}$ \\
\hline $15 h 00-15 h 15$ & $\begin{array}{l}\text { Muriel AUBERSON } \\
\text { Department of Pharmacology and } \\
\text { Toxicology - UNIL }\end{array}$ & $\begin{array}{l}\text { GLUT9 and uric acid handling by the } \\
\text { kidney }\end{array}$ \\
\hline $15 h 15-15 h 30$ & $\begin{array}{l}\text { Fabienne MAURER } \\
\text { Service of Medical Genetics } \\
\text { CHUV }\end{array}$ & $\begin{array}{l}\text { Mapping genetic variants associated to } \\
\text { beta-adrenergic responses in inbred mice }\end{array}$ \\
\hline $15 h 30-15 h 45$ & $\begin{array}{l}\text { Maxime PELLEGRI N } \\
\text { Service of Angiology } \\
\text { CHUV }\end{array}$ & $\begin{array}{l}\text { Critical role of Angiotensin II type } 1 \\
\text { receptor on bone marrow-derived cells in } \\
\text { the development of vulnerable } \\
\text { atherosclerotic plaque in } 2 \text {-Kidney, 1-Clip } \\
\text { ApoE-/- mice }\end{array}$ \\
\hline
\end{tabular}

